\title{
THE EFFECT OF FEDERAL TREATIES ON STATE WORKMEN'S COMPENSATION LAWS
}

\author{
JAMES H. DAFFER $\dagger$
}

\begin{abstract}
Thirty-one American jurisdictions discriminate against nonresident alien dependents in their workmen's compensation laws. Yet the federal govermnent has apparently obligated itself by treaty to assure nondiscriminatory treatment for nationals of contracting conntries. While it seenus clear under the supremacy clause of the federal constitution that inconsistent state legislation cannot stand, courts, both state and federal, have demonstrated a reluctance to construe treaty provisions in a way which would bring them into conflict with state laze. In this Article, Mr. Daffer charts the progress toward this impasse, treats the problems which it raises, and offers an approach for claimants whose rights to equal treatment arise under recent treaties.
\end{abstract}

A coal miner who has recently immigrated from Germany is killed in an explosion in a West Virginia mine. His widow, a German national living in Munich, seeks recovery under the West Virginia workmen's compensation law. That law denies all benefits to nonresident alien dependents. ${ }^{1}$ Yet article IV of the German-American commercial treaty of 1954 purports to provide for nationals of both countries compensation equivalent to that received by citizen workers and dependents. ${ }^{2}$ Will the local statute give way to the treaty provision?

This Article will explore that question and its implications. With article IV as a focal point, it will trace (1) the rise of discriminatory workmen's compensation laws in the United States; (2) the long struggle of nonresident citizens of other countries, particularly Italy, to defeat such laws in reliance on treaty provisions; (3) the opposing forces in the controversy about the limits of the national treaty power,

$\dagger$ Member, San Francisco Bar; A.B., 1950, Yale University; M.A., 1951, University of Wisconsin; LL.B., 1957, University of California.

1. W. VA. CODE ANN. $\$ 2540(1)$ (1955).

2. "Nationals of either Party shall be accorded national treatment in the application of laws and regulations within the territories of the other Party that establish a pecuniary compensation or other benefit or service, on account of disease, injury or death arising out of and in the course of employment or due to the nature of employment." Treaty of Friendship, Commerce, and Navigation With Germany, Oct. 29, 1954 [1956] 2 U.S.T. \& O.I.A. 1839, T.I.A.S. No. 3593. All major commercial treaties signed by the United States since 1923 similarly have some kind of clause dealing with workmen's compensation benefits. For listings and discussions of recent commercial treaties concluded by the United States, see three articles by Robert Wilson: Postwar Commercial Treaties of the United States, 43 Am. J. InT'L L. 262 (1949); Access-to-Coutsts Provisions in United States Commercial Treaties, 47 AM. J. INT'L L. 19 (1953) ; A Decade of New Commercial Treaties, 50 AMr. J. INT'L L. 927 (1956). See also, Hynning, Treaty Law for the Private Practitioner, 23 U. CHI. L. REv. 36 (1955). For specific discussion of workmen's compensation provisions, see Bayirch, Conflict Law IN UNITEd States Treatres (1955); Hyde \& Watson, The Equities of Non-Resident Alien Dependents Under Workmen's Compensation Laws, 7 ILL. L. REv. 414 (1913). 
the reaction of the State Department to that controversy, and the resultant change in the workmen's compensation treaty provision; (4) the continuing difficulties to be faced by nonresident German dependents asking compensation in certain states under article IV; and (5) arguments by which a court might be persuaded to enforce such provisions against discriminatory state law.

\section{Claimant's Rights in the Absence of a Treaty}

Seventeen states and Puerto Rico give nonresident alien dependents full recovery benefits by statute ${ }^{3}$ or court decision. ${ }^{4}$ The remaining thirty-one American states, Alaska, Hawaii, and the District of Columbia discriminate against nonresident alien dependents in their workmen's compensation laws. ${ }^{5}$ Nonresident alien recovery thus becomes an issue only in those states and territories with discriminatory laws. ${ }^{6}$ But these laws exist in a strong majority of American jurisdictions; ${ }^{7}$ and the history of those statutes reveals much about the problems facing nonresident alien dependents ${ }^{8}$ even when armed with treaty provisions.

3. Five states expressly include nonresident alien dependents in their statutory benefits. 2 LARSON, WORKMEN'S COMPENSATION 117, 552-53 (1952).

4. Ten states and Puerto Rico have no provisions relating to nonresident alien dependents. Ibid. Although the issue has apparently not been litigated in all of those states, courts in nearly all have construed the silent statutes as giving full and equal benefits to nonresident alien dependents. See, e.g., In re Derinza, 229 Mass. 435, 118 N.E. 942 (1918). The United States Supreme Court has ruled in favor of nonresidents in situations involving statutes without specific provision. Madera Sugar Pine Co. v. Industrial Acc. Comm'n, 262 U.S. 499 (1923). There is accordingly little doubt that the dependent would be protected in states with silent statutes. Although California deprives nonresident aliens of the presumption of dependency, it is usually classed as a nondiscriminatory state and it is so categorized here. 2 LARSON, WoRkMEN's COMPENSATION 117 (1952).

5. Four states entirely exclude nonresident alien dependents from any benefits. The rest lower benefits by arbitrarily cutting normal awards (usually to one-half but often to less), restricting possible beneficiaries, allowing commutation to reduced lump sums, etc. There are no discriminatory provisions regarding resident aliens. Id. at 552-53; Digest of WorkMen's Compensation Laws of the United States and TERRITORIES passim (16th ed. 1957); see note 14 infra.

6. But see Liimatainen v. State Industrial Acc. Comm'n, 118 Ore. 260, 246 Pac. 741 (1926), in which a nonresident alien dependent was denied right of appeal in Oregon courts because she did not reside in any county in the state. While Oregon has a discriminatory statute in the usual sense, this collateral kind of discrimination could conceivably arise in one of the states without discriminatory provisions.

7. Five states of this majority have clauses stating that the provision will not apply if "otherwise provided by treaty," as the Illinois clause is worded. ILx. ANN. STAT. ch. 48, \$144(j) (Smith-Hurd 1950). But the language is, in all states with this reservation, vague enough so that nonresident alien dependents invoking treaties cannot be fully certain of protection, and the question has apparently not been litigated. Digest OF Workmen's CoMpensatton LAWS OF THE UNTTED States and TERRTTORIES passim (16th ed. 1957).

8. Cases arising in this context invariably involve a workman's death since if the workman were merely injured he could bring his own action. The bulk of the statutes only require residency at the time of the accident, and the workman would obviously qualify. The fact that nonresident alien dependents are deprived of full recovery in death cases only does, of course, make this a particularly aggravated form of discrimination. 
Nonresident alien dependents otherwise qualified were rarely denied recovery under wrongful death statutes ${ }^{9}$ or under the forerunners of workmen's compensation, ${ }^{10}$ employer's liability statutes. ${ }^{11}$ Yet the great waves of laboring immigrants had not reached the United States. ${ }^{12}$ Their coming coincided with the development of workmen's compensation in America, ${ }^{13}$ and employers of immigrant workmen were strongly influential ${ }^{14}$ in the placing of discriminatory clauses in most of the swiftly multiplying compensation laws.

In the absence of treaty provisions, dependents have been wholly unsuccessful in obtaining equal compensation under these statutes. ${ }^{15}$ The courts have rejected all arguments that such discrimination is a denial of equal protection secured by the fourteenth amendment. ${ }^{16}$ Furthermore, many dependents suing for compensation under so-called voluntary laws have been foreclosed from bringing wrongful death actions as well as denied recovery under the workmen's compensation law. ${ }^{17}$

9. Cases are collected in Annot., 138 A.L.R. 686 (1942). Contra, Deni v. Pennsylvania R.R., $181 \mathrm{~Pa} .525,37$ Atl. 558 (1897), discussed in text beginning at note 29 infra.

10. For historical background of the workmen's compensation laws see 1 LARSoN, WorkMEN's COMPENSATION 29 (1952) and Riesenfeld, Contemporary Trends in Compensation for Industrial Accidents Here and Abroad, 42 CALIF. L. REv. 531 (1954).

11. See, e.g., Mulhall v. Fallon, 176 Mass. 266, 57 N.E. 387 (1900), and McGovern v. Philadelphia \& Reading R.R., 235 U.S. 389 (1914). The latter assured nonresident alien dependents full benefits under the Federal Employers' Liability Act of 1908, ch. 236,35 Stat. 556.

12. The flow of South European immigrants began rising in 1902, reaching its peak in 1914. N.Y. World Telegram, 1957 World Almanac 651 (1956). Large numbers of these filled the growing need for industrial labor. U.S. DEP'T of COMmerce Census Bureau, Historical Statistics of the United States 1789-1945, at 32-33, 63-65 (1949).

13. The beginning of workmen's compensation in the United States is usually set at 1911, the year New Jersey passed the first permanent law. By 1920, all but eight states had similar laws. 1 LARSON, WORKMEN's COMPENSATION 35-39 (1952).

14. For a discussion of the origins of the discriminatory provisions, see Hyde \& Watson, supra note 2 , at 414-26. As they point out, the legislative draftsmen and committees heard only the advocates of discrimination because only that group was organized and articulate. Hyde and Watson also cite specific instances of employers' counsel arguing for discriminatory sections before legislative committees. It seems more than coincidental that two of the largest coal-producing states, Pennsylvania and West Virginia, were until 1956 among the five states expressly excluding nonresident alien dependents from any benefits. In that year, Pennsylvania amended its statute to allow one-half the normal award to certain classes of dependents living in countries that similarly aided American dependents. PA. STAT. ANN. tit. 77, \&563 (Supp. 1957). West Virginia remains one of the four states of complete exclusion. W. VA. CODE ANN. §2540(1) (1955).

15. See, e.g., Continental Cas. Co. v. Industrial Comm'n, 68 Utah 334, 250 Pac. 145 (1926), and Maryland Cas. Co. v. Chamos, $203 \mathrm{Ky} .820,263$ S.W. 370 (1924).

16. Ibid. The words of the amendment seem conclusive: "No State shall . . . deny to any person within its jurisdiction the equal protection of the laws." A nonresident alien dependent, of course, is never considered as being within the jurisdiction of the state.

17. Because of a constitutional point, many of the workmen's compensation laws were placed on a "voluntary" basis in that the employer and the employee were not 
It seems not exaggerated, then, to say that courts and legislatures have dealt harshly with nonresident alien dependents when unfettered by treaty guarantees. The justifications listed by the courts for the discriminatory provisions are weak ${ }^{18}$ and bear little relation to what were apparently the real motivations for the laws. ${ }^{19}$ Even the admitted difficulty of administering compensation over long distances has little merit as an argument for discrimination. ${ }^{20}$

Yet the easily rebutted rationalizations of the discriminatory laws are not nearly so important as the fact that the laws remain embedded in their economic, historical foundations. Nondiscriminatory workmen's compensation developed in Europe on a national level and in a

bound by them unless they had so agreed. 1 LARSON, WORKMIEN'S COMPENSATION 38 (1952). See note 46 infra for a discussion of this trap as set, for example, in De Biasi v. Normandy Water Co., 228 Fed. 234 (D.N.J. 1915). About one-half of the states still have voluntary laws. Riesenfeld, Contemporary Trends in Compensation for Industrial Accidents Here and Abroad, 42 CALIF. L. Rev. 531 (1954). See also the related case of Bjolstad v. Pacific Coast S.S. Co., 244 Fed. 634 (N.D. Cal. 1917), an interesting conflicts case involving choice of law and an alien bound by a discriminatory statute when he thought he was covered by a nondiscriminatory statute.

18. The principal rationalizations and the obvious countering arguments are: (1) Workmen's compensation was designed to keep workers and dependents from being public charges; dependents overseas will not become public charges in this jurisdiction so why should they be compensated? See, e.g., Maryland Cas. Co. v. Chamos, $203 \mathrm{Ky} .820,263 \mathrm{~S} . \mathrm{W} .370$ (1924). The primary answer to this is that the whole workmen's compensation idea has been far more than a means of keeping workers and their dependents off the relief rolls. Its essential purpose has often been said to be the protection of the worker on the job or in the event of accident, with the employer and his customers bearing the costs because of the inherent dangers of producing the goods needed by society. See, e.g., 1 LARSON, Workmen's Compensation 5 (1952) ; Andrews, Discrimination Against Non-Resident Dependents, 13 Ax. LaB. LEG. REv. 232 (1923). Most of the discriminating states, moreover, do give benefits to residents of the United States and, in some cases, Canada, who will not become public charges in the home jurisdiction. DIGEST OF WORKMEN's Compensation LAwS OF THE UNITED STATES AND TERrTtorIes (16th ed. 1957). Finally, the fact that most states (all but four) give some compensation to nonresident alien dependents shows the inconsistency of the public-charge argument and underscores the fact that nonresident alien dependents need the protection of the workmen's compensation laws as much as resident dependents. (2) It costs less to live abroad. Nonresident alien dependents should therefore be paid less compensation. See, e.g., Continental Cas. Co. v. Industrial Comm'n, 68 Utah 334, 250 Pac. 145 (1926). While this ground hardly seems worthy of argument, it appears to have been a favorite of employers' lobbyists when the compensation laws were being enacted. Hyde \& Watson, supra note 2 , at 420-23. Costs of living abroad vary, of course, and in some cases would be higher than in parts of the United States. Furthermore, the income of the dependents having been determined by an American wage scale, they should receive no less a benefit on the death of the wage earner than resident dependents. Both arguments (1) and (2) are cited again and again by the courts denying recovery to nonresident alien dependents. The more reasonable argument of high costs and difficulty of administration has not been used by the courts, perhaps a demonstration that the judiciary has not felt compelled to give good justification for enforcing the discriminatory laws. See note 20 infra.

19. See text accompanying note 14 supra.

20. The contention is restated in 2 LARSON, WORKMEN's COMPENSATION 117-18 (1952). See the reply in In re Derinza, 229 Mass. 435, 441, 118 N.E. 942,945 (1918): "The difficulties . . appear to be no greater in one class of cases than in the other. .. [T] hey are legislative rather than judicial questions." 
milieu of emigration. ${ }^{21}$ Compensation laws arose in the United States within individual state units and in the midst of an immigratory flood. State discriminatory statutes have been remarkably stable ${ }^{22}$ and continue to be supported by local industry, legislatures, and judiciary. In short, these laws represent the underlying legal structure, founded on the residual powers of the states, upon which the federal government has from time to time sought to superimpose contrary commands through the joint use of the treaty power and the supremacy clause. We must now consider how successful these efforts have been.

\section{Claimant's Rights Under Prior Treaties: The Maiorano Case}

A year after the signing of the German-American Treaty of Friendship of 1954, nonresident alien dependents might well have rejoiced in a decision that, on its face, was the first strong precedent for giving them equal compensation under a treaty provision when such equality was otherwise denied by state law.

In Iannone v. Radory Constr. Corp., ${ }^{23}$ the New York Supreme Court held, in a decision affirmed per curiam by the Court of Appeals, ${ }^{24}$ that an alien dependent residing abroad could recover full benefits under a treaty provision that overcame a New York statute limiting her award to one-half the regular amount. Relying on the clear wording of article XII of the 1948 commercial treaty with Italy, ${ }^{25}$ the court gave equal compensation to an Italian widow for the death of her husband in an industrial accident. It rejected several strong arguments of the

21. Hyde \& Watson, stipra note 2, at 416-17. The European laws came two decades earlier, however. See 1 LARSON, WORKMEN's CoMpensation 33-35 (1952), for historical background.

22. Few states have changed their original law as to nonresident alien dependents. The result of the changes that have been made is, if anything, a net loss for nonresidents. New Hampshire and New Jersey, for example, have removed former restrictions; but Wisconsin, Iowa, and Michigan have added discriminatory provisions where there were none originally. Andrews, supra note 18, at 233; Hyde \& Watson, stipra note 2, at 414; see DigEsT OF WORKMEN'S COMPENSATION LAWS OF THE UNITED States AND TERRITORIEs (16th ed. 1957). But see note 14 supva.

23. 285 App. Div. 751, 141 N.Y.S.2d 311 (1955).

24. 1 N.Y.2d 671, 150 N.Y.S.2d 199 (1956).

25. "The nationals of either High Contracting Party, regardless of alienage or place of residence, shall be accorded rights and privileges no less favorable than those accorded to the nationals of the other High Contracting Party, under laws and regulations within the territories of such other High Contracting Party that (a) establish a civil liability for injury or death, and give a right of action to an injured person, or to the relatives, heirs, dependents, or personal representative, as the case may be, of an injured or deceased person or that (b) grant to a wage-earner or an individual receiving salary, commission, or other remuneration, or to his relatives, heirs or dependents, as the case may be, a right of action, or a pecuniary compensation or other benefit or service, on account of and in the course of employment or due to the nature of employment." Treaty With Italy Respecting Friendship, Commerce, and Navigation, Feb. 2, 1948, art. XII, 63 Stat. 2255, T.I.A.S. No. 1965. 
compensation board ${ }^{26}$ in concluding that "section 17 of the Workmen's Compensation Law is inconsistent with the treaty and must give way to superior national policy." 27

Iannone represents the culmination of more than half a century of struggle by nonresident Italian dependents to obtain equal compensation by treaty. Although perhaps atypical in this regard, the Italian experience is nevertheless instructive. The history of this struggle reveals the pitfalls which still await nonresident dependents of other nations who have yet to attain this equality. ${ }^{28}$

The initial use of treaty law by Italians in this context was in wrongful death and employer's liability actions against negligent employers. Two opposing lines of cases in Pennsylvania and Massachusetts formed the groundwork of the controversy that arose. In Deni v. Pennsylvania R.R..$^{29}$ a citizen of Italy, nonresident of Pennsylvania, was denied compensation for her son's industrial death on the theory that the state wrongful death statute had no application outside the boundaries of Pennsylvania. ${ }^{30}$

Mulhall $v$. Fallon, ${ }^{31}$ to the contrary, permitted wrongful death recovery to an Irish national, nonresident of Massachusetts, Chief Justice Holmes of the Massachusetts Supreme Judicial Court saying, "We cannot think that workmen were intended to be less protected if their mothers happen to live abroad." $\mathbf{2 2}$

Neither Deni nor Mulhall involved a treaty provision; both turned solely on the construction of the state wrongful death statute. But in Maiorano v. Baltimore \& O.R.R., ${ }^{33}$ both the Supreme Court of Pennsylvania and the Supreme Court of the United States were called upon to determine the effect of a treaty provision upon the narrow construction of the Pennsylvania statute rendered in Deni. The State court ruled that a nonresident Italian dependent could not invoke article III of the

26. Chief among these arguments was the theory that the Italian dependent was, in fact, receiving "national treatment" since even nonresident alien dependents of American citizens were given reduced benefits by the statute in question. National treatment was the basic standard of the treaty provision being invoked. See note 25 supra. This contention and the national treatment standard are discussed more fully in the text beginning at note 83 infra.

27. 285 App. Div. at 755, 141 N.Y.S.2d at 315 .

28. In view of the many Italian immigrant laborers coming to the United States in the first part of the twentieth century, it is not surprising that Italian claimants have made the case law in this field. U.S. DEP'T OF COMMERCE CENSUS BUREAU, Historical Statistics of the United States 1789-1945 (1949).

29. $181 \mathrm{~Pa} .525,37$ Atl. 558 (1897).

30. The statute itself contained no discriminatory provisions, but the judges evidently felt bound by "the general rule that we do not legislate for persons beyond our jurisdiction." Id. at 530,37 Atl. at 560 .

31. 176 Mass. 266, 57 N.E. 387 (1900).

32. Id. at $269-70,57$ N.E. at 388 .

33. 216 Pa. 402, 65 Atl. 1077 (1907), aff'd, 213 U.S. 268 (1909). 
1871 Italian commercial treaty ${ }^{34}$ as a means of escaping the Deni conclusion that the wrongful death statute was not available to nonresident aliens. This protection-of-person article applied only to Italian nationals living in the United States. The United States Supreme Court agreed but was disturbed by plaintiff's arguments that the treaty did protect her rights in letter and spirit. ${ }^{35}$ Still, concluded Justice Moody, the treaty was not intended to reach so far abroad as to protect nonresident alien dependents. ${ }^{36}$

The United States Supreme Court considered itself bound by the restrictive construction given the state wrongful death statute by the Pennsylvania court in Deni and in the instant case. Moreover, the express wording of article III made it highly vulnerable to a narrow reading which, by restricting its operation, would prevent it from coming into conflict with the discriminatory provisions of the state law. ${ }^{37}$ Neither the state nor national court was convinced by arguments that the deceased workman, ${ }^{38}$ rather than the dependent, should be considered the object of protection and source of right under both the statute and treaty. As a result of these partly fortuitous factors, the Maiorano case thus went on record as a strong precedent against permitting nonresident alien dependents to avail themselves of generalized treaty provisions against contrary interpretations of state law. When the controversy over treaty interpretation in this area shifted

34. "The citizens of each of the high contracting parties shall receive in the states and territories of the other the most constant protection and security for their persons and property, and shall enjoy in this respect the same rights and privileges as are or shall be granted to the natives on their submitting to the conditions imposed on the natives." Treaty With Italy, Feb. 26, 1871, 17 Stat. 845,846 , T.S. No. 177.

35. Her contention that the purpose of the statute was to raise the standard of care and thus give greater protection to those in danger of death, not just their dependents, said the Court, was "not without force. . . . Doubtless one reason which has induced legislators to give surviving relatives an action for death has been the hope that care for life would be stimulated." 213 U.S. at 275.

36. "We are of the opinion that the protection and security thus afforded [under the treaty] ... are so remote and indirect that the contracting powers cannot fairly be thought to have had them in contemplation." Ibid.

37. A firm argument on article XXIII, the access-to-courts provision, would have been far more difficult to reject as a matter of treaty language and intent than the argument actually made on article III. Article XXIII said or implied nothing about having to reside in the jurisdiction in order to use the courts. The Court would have had nothing solid on which to base its strict construction of the wording. See Wilson, Access-to-Courts Provisions in United States Commercial Treaties, 47 AM. J. INT'L L. 19, 42 (1953). In Conflict Law IN United States Treaties (1955), however, Bayitch views the ultimate workmen's compensation provision as a refinement of "protection-of-person" articles. That is, the workmen's compensation provision as historically developed was designed to broaden the protection of the alien person rather than give a freer access to courts. If this be true, the historical basis of the workmen's compensation provision could become a weapon for the dependent arguing that he derived his rights from the worker's right to protection on the job.

38. It is not entirely clear from the reports whether plaintiff's decedent had been fatally injured while acting as an employee or as a paying passenger. It is doubtful that the status of decedent affected the decision, however. 
to workmen's compensation statutes ${ }^{39}$ that specifically excluded nonresident alien dependents, ${ }^{40}$ Maiorano was an even stronger bulwark against construing treaty provisions in favor of aliens thwarted by those statutes.

\section{Claimant's Rights Under Prior Treaties: The Liberato Case}

Shortly after the Maiorano decision, the Italian government formally protested that the treaty of 1871 did allow nonresident aliens standing to sue under a statute of the Pennsylvania type. ${ }^{41}$ The upshot was an amendment to the 1871 treaty designed to "define more accurately the rights of their respective citizens in the territories of the other." 42 Revising the protection-of-person article that the plaintiff in Maiorano had most strongly urged, the negotiators agreed that citizens should enjoy protection of their persons,

"including that form of protection granted by any State or national law which establishes a civil responsibility for injuries or death caused by negligence or fault and gives to relatives or heirs of the injured party a right of action, which right shall not be restricted on account of the nationality of said relatives or heirs. . . " 43

The remedial effect of this change in the wording of the treaty was soon dissipated, however, by a change in the pattern of American law. During this period the existing wrongful death and employers' liability statutes were being eclipsed by new "voluntary" workmen's compensation laws ${ }^{44}$ which relieved claimants from the burden of showing employers' negligence, but which also closed the channel of relief formerly available through the wrongful death statutes. Because the amendment to article III was drafted at a time when the prevailing type of state legislation involved some showing of fault, the legislation to which its restrictive effect was directed was described in those terms. Consequently a court disposed to construe the treaty in a way which would prevent its coming into conflict with and overriding state law could define its terms as pertaining only to negligence actions and thus of no effect upon workmen's compensation legislation. ${ }^{45}$

39. For historical background of workmen's compensation and its antecedents, see 1 Larson, Workmen's Compensation 5-39 (1952).

40. See text beginning at note 3 supra.

41. Wilson, Access-to-Courts Provisions in United States Commercial Treaties, 47 AM. J. INT'L L. 19, $42-43$ (1953).

42. Treaty With Italy Amending Article III of the Treaty of Commerce and Navigation of February 26, 1871, signed Feb. 25, 1913, 38 Stat. 1669, 1670, T.S. No. 580 .

43. Ibid.

44. See text beginning at note 12 supra.

45. There were some cases on which a construction favoring nonresident alien rights might have been based. In Vietti v. George K. Mackie Fuel Co., 109 Kan. 
This was the construction adopted by the United States Supreme Court in Liberato $v$. Royer. ${ }^{48}$ Claimant argued that the treaty, by a reasonable reading of its terms, operated to restrict the discriminatory effect of state workmen's compensation laws as well as wrongful death actions, since the language of the amendment granted protection to citizens of their persons, "including" that form of protection given by wrongful death statutes, and hence, by implication, including other forms of protection as well. ${ }^{47}$ The Supreme Court, per Holmes, J., who twenty-six years earlier had not thought that "workmen were intended to be less protected if their mothers happened to live abroad," 48 rejected this argument, and denied recovery to nonresident Italian parents who had been entirely excluded under the Pennsylvania workmen's compensation statute, on the ground that the amendment was not intended to cover workmen's compensation protection.

The effect of Liberato was to undermine completely the efforts made in the amendment to article III toward protecting the nonresident alien against discriminatory legislation in the states. ${ }^{49}$ Claimants, frustrated by discriminatory workmen's compensation laws to which the protection of treaty was held not to extend, found the avenues of

179, 197 Pac. 881 (1921), the court held resident alien dependents protected under the Italian treaty as amended in 1913-despite a discriminatory state law. The reasoning of the case would surely have included nonresident alien dependents as well. McGovern v. Philadelphia \& Reading R.R., 235 U.S. 389 (1914), and Madera Sugar Pine Co. v. Industrial Acc. Comm'n, 262 U.S. 499 (1923), were decided on other than treaty grounds but could in their reasoning have easily formed a basis for a Supreme Court holding that nonresident alien dependents could overcome discriminatory workmen's compensation laws by invoking treaty provisions and the supremacy clause.

46. 270 U.S. 535 (1926). For examples of cases preceding Liberato see DeBiasi v. Normandy Water Co., 228 Fed. 234 (D.N.J. 1915), and Frasca v. City Coal Co., 97 Conn. 212, 116 Atl. 189 (1922). Both involved voluntary workmen's compensation acts under which the employee had theoretically agreed to be bound by all provisions of the compensation law. Dependents were accordingly bound too and could not defeat the deceased's contract by use of treaty provision. See note 17 supra. Furthermore, continued both courts, the 1913 amendment was restricted to negligence actions and thus inapplicable in a workmen's compensation proceeding. The Vietti court read the 1913 amendment more liberally (and probably more logically) as dealing with compensation actions as well as negligence actions: "It will be noted that this form of protection is only one of the rights for which provision was made. The protection guaranteed is equality and reciprocity of rights including the one specifically mentioned and the emphasis placed on the one does not exclude others plainly provided for in the treaty. The provisions of the treaty are to be given reasonable interpretation, one that will effectuate the obvious purposes of the contracting powers. . The limitations of the [Kansas] statute being against both the letter and the spirit of the treaty, it must be held to be nugatory as against the plaintiffs." Vietti v. George K. Mackie Fuel Co., 109 Kan. 179, 182, 197 Pac. 881, 883 (1921).

47. Treaty With Italy Amending Article III of the Treaty of Commerce and Navigation of February 26, 1871, signed Feb. 25, 1913, 38 Stat. 1669, 1670, T.S. No. 580 . See note 46 supra.

48. Mulhall v. Fallon, 176 Mass. 266, 269-70, 57 N.E. 387, 388 (1900). See text accompanying note 31 supra.

49. See, e.g., Norella v. Maryland Cas. Co., 216 Ky. 29, 287 S.W. 18 (1926), one of many cases following the Liberato precedent. 
relief under the wrongful death acts, to which the terms of the treaty did expressly extend, now likewise closed. This result was achieved through the fiction that the worker had consented to waive his rights under the wrongful death statutes as a condition to receiving the benefits of the workmen's compensation laws, ${ }^{50}$ even though, because of their discriminatory provisions, no benefits might accrue to his dependents under them.

The Liberato decision, in affirming the canon of construction implicit in Maiorano, again amply demonstrated the reluctance of the Court to give to the treaty a meaning which would bring the federal government into conflict with the states over the administration of state welfare programs. It taught treaty negotiators in the clearest terms that if they wished to nullify the discriminatory provisions of state workmen's compensation laws, their intent would have to be expressed in language of indubitable meaning.

\section{The Model Provision of the 1923 Treaty With Germany}

None of the courts construing the Italian treaty and its amendment against nonresident alien dependents, it is true, violated the letter of the supremacy clause of the Constitution. ${ }^{51}$ Nor did they violate any of the so-called canons of treaty interpretation. ${ }^{52}$ But it may be doubted that the intentions of the high contracting parties were fulfilled. ${ }^{3}$ When the treaty wording was such that the court could retreat into the "clear meaning" doctrines, ${ }^{54}$ or so ambiguous that it could draw its own conclusions, negotiators' intentions were easily obscured. This was particularly so when the treaty conflicted with a state law.

Thus, one solution for the plight of the nonresident Italian dependent was more explicit wording. While the amended Italian treaty

50. See 270 U.S. at 539.

51. U.S. Const. art. VI, \$2.

52. At least one writer has concluded that the canons all come down to the obvious principle of using all the evidence available to determine what the parties meant to accomplish when they wrote the treaty. CHANG, The Interpretation of Treaties by Judictal. Tribunals 182 (1933). Chang similarly classifies the "rule of liberal construction" so long venerated in American courts. Id. at 185. In this sense, courts interpreting treaties are not bound by rules of interpretation at all, particularly when construing a provision for the first time and thus freed from any precedent. See Antosz v. State Compensation Comm'r, 130 W. Va. 260, 43 S.E.2d 397 (1947). If this conclusion is correct then it would seem that these courts did violate the principal canon of treaty interpretation.

53. Witness the Italian protest following Maiorano and the willingness of the United States to re-word the treaty to cover industrial accident at a time when workmen's compensation laws were just beginning to have significance for alien workmen in the United States. See text beginning at note 42 supra.

54. See Hauenstein v. Lynham, 100 U.S. 483 (1879), and CHANG, The INTERpretation of Treaties by JUdicial TRIbUNals 58-60 (1933). 
remained unchanged until 1948, the American Government began meeting the need for other nationalities in 1923.

In December of that year, the United States signed a commercial treaty with Germany ${ }^{55}$ that indicated generally the new American attitude toward international human rights and social welfare ${ }^{56}$ and included specifically a guaranty of equal workmen's compensation to nonresident alien dependents :

"With respect to that form of protection granted by National, State, or Provincial laws establishing civil liability for injuries or for death, and giving to relatives or heirs or dependents of an injured party a right of action or a pecuniary benefit, such relatives or heirs or dependents of the injured party, himself a national of either of the High Contracting Parties and within any of the territories of the other, shall, regardless of their alienage or residence outside of the territory where the injury occurred, enjoy the same rights and privileges as are or may be granted to nationals, and under like conditions." 67

As if to reaffirm and underscore article II, the parties then provided in article XXV for convenient payment of workmen's compensation to nonresidents :

"A consular officer of either High Contracting Party may in behalf of his non-resident countrymen receipt for their distributive shares derived from estates in process of probate or accruing under the provisions of so-called Workmen's Compensation Laws or like statutes...."58

In view of the precise wording of both provisions, the negotiators of each nation must have been fully aware of the adverse decisions affecting nonresident Italian dependents seeking compensation. ${ }^{69}$ Moreover, certain members of Congress and the executive branch were deeply concerned that treaty rights of aliens generally were not being enforced within the states. ${ }^{60}$ The new form of treaty was the product of that concern.

55. Treaty With Germany of Friendship, Commerce and Consular Rights, Dec. 8, 1923, 44 Stat. 2132, T.S. No. 725.

56. It is interesting to note that, despite congressional defeat of American participation in the Ieague of Nations, Wilsonian idealism arising from World War I and this nation's role in it were reflected in the commercial treaty program. This program remained at odds, of course, with the anti-internationalist temper then prevalent in the United States.

57. Treaty With Germany of Friendship, Commerce and Consular Rights, Dec. 8, 1923, 44 Stat. 2132, 2134, T.S. No. 725. (Emphasis added.)

58. Id. at 2154. (Emphasis added.)

59. Although Liberato v. Royer, 270 U.S. 535 (1926), had not yet been decided.

60. See, e.g., Hearings Before the Committee on Foreign Relations of the Senate on the Protection of Aliens and Enforcement of their Treaty Rights, 67th Cong., 1st Sess. passim (1922). 
The above-quoted provisions of the 1923 German treaty were repeated word-for-word ${ }^{61}$ in all twelve major commercial treaties signed by the United States between 1923 and $1946 .^{62}$ There is no evidence that the treaties were questioned in the courts during that period. Presumably, nonresident alien dependents meeting the provisions were able to invoke their clear wording successfully. ${ }^{63}$

Yet the ineffective Italian treaty of 1871 , with its 1913 amendment, still remained, and it was not until negotiation of the 1948 treaty and the resulting Iannone decision that the Italian efforts bore fruit. ${ }^{64}$

The history of those efforts reveals (1) that state and federal courts are extremely reluctant to overthrow domestic law in this area when that result can be avoided by strict interpretation of a treaty provision; (2) that this is true even when the treaty's broad purpose, spirit, and intent are contrary to that state discriminatory law; and (3) that when confronted with unmistakable treaty language, courts just as surely will invalidate an opposing state law and thus enforce national policy against local policy.

\section{The History and Content of Article IV}

Had the 1954 German treaty been based on the 1923 German or 1948 Italian model, this lesson of legal history would be of purely academic interest. The American executive branch, speaking through the treaty officers of the State Department, apparently had full intention initially of enforcing and continuing the expanded form of workmen's compensation guarantees seen in the Italian agreement, despite threatened conflict with state law.

Mr. William Connolly, then director of the Bureau of Labor Standards, had evidently been working with the State Department on

61. There was a slight but insignificant change in the wording of the consular provision of one treaty. Treaty With Poland of Friendship, Commerce, and Consular Rights, June 15, 1931, 48 Stat. 1507, T.S. No. 862. Beginning with the Liberian treaty of 1938, the State Department began handling consular rights with separate agreements. But those separate agreements often were delayed or never concluded, and the workmen's compensation provision was weakened accordingly. Treaty of Friendship, Commerce, and Navigation With Liberia, Aug. 8, 1938, 54 Stat. 1739, T.S. No. 956. But see text beginning at note 112 infra.

62. Treaties cited in Hynning, Treaty Law for the Private Practitioner, $23 \mathrm{U}$. CHI. L. REV. 36, 71 (1955).

63. See, e.g., Antosz v. State Compensation Comm'r, 130 W. Va. 260, 43 S.E.2d 397 (1947), in which a Polish alien was successful in defeating a discriminatory law with the aid of the 1931 Polish Treaty workmen's compensation and consular provisions based on the 1923 German model clauses. The same court had six years earlier rejected a like contention of an Italian national still bound by the 1913 amendment, demonstrating the importance of treaty wording in this context. Micaz v. Compensation Comm'r, 123 W. Va. 14, 13 S.E.2d 161 (1941). The court did not note the fact, but the United States and Italy had suspended the 1871 treaty, including the 1913 amendment, in 1937 by mutual agreement.

64 . See text beginning at note 23 supra. 
the specific problem of workmen's compensation treaty provisions. ${ }^{65}$ In 1949, the State Department requested that he address the International Association of Industrial Accident Boards and Commissions on the subject. ${ }^{66}$ This group is composed largely of the men who administer and develop the state workmen's compensation laws. The State Department was clearly interested in implementing its new treaty policy toward workmen's compensation in the states and chose this as the logical forum in which to air its intentions and gauge the reaction. Connolly's words are highly significant in analyzing this period of flux:

"As a result of recent ratification of a trade treaty with Italy, the State Department has asked me to discuss with you the effect of these treaties on the rights of alien workers under the state workmen's compensation laws [there are similar provisions in twelve other treaties and more will soon be negotiated]. The question again arises, therefore, as to how these treaties, which are considered to be the supreme law of the land, affect the payment of workmen's compensation benefits to alien workers. . . . The provision in the treaty with Italy represents a clarification of the provision which appears in the older treaties [and while the Supreme Court has not decided the scope of the Italian provision, the West Virginia Supreme Court has, for a similar provision, in the Antosz ${ }^{66 a}$ case]. In view of this court decision, it may be advisable for those States with special provisions in respect to payments of benefits to non-resident alien dependents to review and study the effect of these treaties on such provisions."

The speaker then listed the states and territories with discriminatory laws. His address indicates both the State Department's full awareness of the controversy and its continuing commitment to the policy of the model provision of the 1923 German treaty, under which nonresident aliens had been able to overcome the discriminatory effects of state workmen's compensation laws. ${ }^{68}$ The tone is one of consolidation and advancement rather than retreat.

Yet, in autumn of this same year, the retreat began that still continues and during the course of which article IV of the German treaty was adopted: a commercial treaty signed with Uruguay No-

65. Proceedings of the Thirty-fifth Amual Convention of the International Association of Industrial Accident Boards and Commissions, 119 DEP'T LABOR BULL. 80 (1949).

66. Ibid. (1947).

66. Antosz v. State Compensation Comm'r, 130 W. Va. 260, 43 S.E.2d 398

67. 119 Dep'T Labor BuLl. 80-81 (1949).

68. See Antosz v. State Compensation Comm'r, 130 W. Va. 260, 43 S.E.2d 398 (1947). See note 63 supra. 
vember 23, 1949, included for the first time the restricted workmen's compensation clause appearing in the 1954 German treaty. ${ }^{69}$

While the evidence is far from conclusive, ${ }^{70}$ it would seem that the executive, in the form of the State Department, changed its policy toward workmen's compensation as a result of unfavorable reaction and pressure from two elements: the United States Senate and state workmen's compensation officials.

The opposition to the Italian-type provisions is inextricably linked with the whole Bricker-amendment approach to the treaty power. Although the Bricker controversy did not explode openly until $1951,{ }^{71}$ its ingredients were brewing actively when the Uruguayan treaty was signed. Adverse to the ratification of multilateral treaties, particularly when sponsored by the United Nations, states-rights proponents bent on containing the treaty power were especially critical of the International Labor Organization, whose constitution the United States had ratified in $1948,{ }^{\mathbf{7 2}}$ and whose principles were firmly grounded on equality of treatment for alien workers. ${ }^{73}$

69. Treaty With Uruguay on Friendship, Commerce, and Navigation, Nov. 23, 1949 (not yet in force nor printed in official listings; reprinted in full, however, in 23 Dep't State Bull. 502 (1950)).

70. One of the greatest difficulties in analyzing treaties and their effect is the sparse and irregular compilation of the treaties themselves and any material associated with them. When congressional hearings can be obtained, they are an illuminating source of evidence. The State Department Bulletin contains significant information. Miscellaneous Government pamphlets are of some value. For a guide to finding treaty texts, no simple task in itself, see Hynning, supra note 62, at 67-75.

71. It is not the intent of the author to explore the labyrinths of the Bricker amendment controversy except as it relates to the subject of this Article. For an excellent commentary, however, see Sutherland, Restricting the Treaty Power, 65 HARV. L. REV. 1305 (1952).

72. The International Labor Organization was formed in 1919 under the aegis of the League of Nations. Through the years, it has formulated numerous "conventions" establishing high standards of labor conditions in almost all of labor's phases. These conventions are circulated to members who have ratified the ILO constitution, and the member nations are free to ratify or reject the conventions. As one would expect, the United States has been among the less active participants, largely because of this country's federal nature. The United States did ratify the ILO constitution in 1934 and again a revised constitution in 1948. The latter instrument is custom-made to help federal-type governments circulate the proposals and conventions of the ILO to individual states for their consideration and possible acceptance through legislation. Since 1948 the United States has nominally cooperated in the ILO program, but it has ratified only five conventions, and those all relate to maritime labor standards in which it is felt the federal government has exclusive interest. One of the conventions, number 19, specifically guarantees equality of treatment to monresident alien dependents (see note 73 infra). This matter, of course, is within the control of the states, and none has endorsed it to date, nor, in all likelihood, will any of the discriminatory states accept it. The ILO has been far more vital in Europe, and the major European nations, including Germany, have ratified several of its conventions, including number 19. INTERNATIONAL LABOUR OFFICE, ThE INTERNATIONAL LABOUR CODE 1951 (1952); 19 Dep'T State Bull. 373-74 (1948) ; Sutherland, supra note 71, at 1333-34.

73. Convention 19 reads, in part, "1. Each member to which this Section applies shall grant to the nationals of any other Member to which it applies, who suffer personal injury due to industrial accidents happening in its territory, or to their 
It was inevitable, then, that Senators aligning themselves with Mr. Bricker would disfavor any bilateral labor provisions that might similarly threaten state legislation. When those provisions seemed to match ILO standards, as the Italian workmen's compensation article certainly had, ${ }^{74}$ that group apparently became alarmed and made its influence felt on the State Department.

While the Italian treaty was ratified before that influence was articulated, 1949 and the Uruguayan treaty clearly mark the dividing line between a strong workmen's compensation clause and one considerably emasculated. Only glimpses are available of the interaction on this issue between the Senate and the State Department. In committee hearings on commercial treaties, questions and answers dealing with the effect of treaties on state law appear again and again after 1949. In 1952, for example, the Assistant Secretary of State for Economic Affairs assured the Senate Foreign Relations Committee that:

"In undertaking treaty commitments [of the Uruguayan type] that would formally confirm to foreigners a substantial body of rights in the United States the Department of State has exercised great care to frame provisions that would be in confirmity with Federal law. . . . Furthermore, where the subject matter covers fields in which the States have a paramount interest . . the treaty provisions have been worked out with the same careful regard for the States' prerogatives and policies that has traditionally characterized agreements of this type." 75

In a more recent hearing, the Deputy Assistant Secretary of State for Economic Affairs replied to the question, "to what extent will the provisions of these [Uruguayan type] treaties affect federal or State law?": "There will be a relationship, of course, but the conflict of laws which have been [troublesome] as in the past has been reduced to a minimum in these agreements and there is no basic inconsistency between the agreements and Federal and State laws." 76 As these

dependents, the same treatment in respect of workmen's compensation as it grants its own nationals. 2. This equality of treatment shall be guaranteed to foreign workers and their dependents without any conditions as to residence. ..." 1 INTERNATIONAL LABOUR OFFICE, The InTERNATIONAI LABOUR CODE 1951, at 627-28 (1952). For states-rights criticism of the ILO, see, e.g., AlLEN, THE TREATY AS AN INSTRUMENT of IEGISLATION passim (1952); Sutherland, supra note 71, at 1333-34. Significantly, the former was written by a federal circuit judge and, in its attack on the treaty power, continually uses the ILO as a "bad example" of what can happen when the states are made subservient to the supremacy clause and the multilateral agreements enforced thereunder.

74. Compare the wording of the Italian provision of 1948 (supra note 25) and convention 19 of the ILO (supra note 73).

75. Hearings Before the Subcommittee on Commercial Treaties of the Senate Committee on Foreign Relations, $82 d$ Cong., $2 d$ Sess. 16 (1952).

76. Hearings Before the Subcommittee on Commercial Treaties of the Sente Committee on Foreign Relations, 84th Cong., 2d Sess. 19 (1956). Time and again throughout this same hearing, the State Department officials were asked for assurance that the treaties involved did not infringe the states' power. Id. at 19, 20, 23. 
excerpts indicate, the Senate, with whose advice and consent treaties are made, ${ }^{77}$ has been the primary factor in the new policy toward workmen's compensation treaty assurances.

But another body has been influential in forming the State Department's cautious new attitude. The immediate reaction to William Connolly's planted speech on the workmen's compensation provisions before the state compensation commissioners was mixed but distinctly cool. ${ }^{78}$ The Department's suggestions were placed in the legislative committee for study, but several officials at the meeting complained that the Department had negotiated provisions closely affecting state laws without consulting the state commissioners. Furthermore, the State Department's proposals were linked with the activities of the ILO in seeking equal treatment for alien workers. ${ }^{79}$

A year later, the mixed reaction had become definitely hostile. Referring to Connolly's speech, the president of the organization opened the 1950 session with the following defense of states' rights in contrast to the treaty power, whether that power be wielded by the American executive or the ILO:

"There has been no effective encroachment on the rights of the States to control their own compensation destiny. I believe that it is the consensus of our members that we should resist Federal encroachment and not surrender the local right to pass the kind of law and to carry out the kind of administration wished by each jurisdiction." 80

The report of the legislative committee continued in the same vein:

"[The] scope of inquiry suggested by the State Department was limited to the possible conflict of laws in the area of treaty provisions with thirteen countries [but] it seems ... that the problem should be dealt with as a whole rather than piecemeal. [The ILO has been urging approval of convention 19.] It may be assumed therefore that the advocacy of this 'equality of treatment' type of provision stems from the International Labor Organization, and is part of the effort of that organization to win local approval of some of its conventions which may affect areas of State or Provincial rights. . . . It appears that members of the International Association of Industrial Accident Boards and Commissions are, in effect, being asked to use their influence to help bring

77. U.S. CoNst. art. II, $\S 2$.

78. 119 DeP't Labor Bull. 80-83 (1949).

79. Ibid.

80. Proceedings of the Thirty-Sizth Annual Convention of the International Association of Industrial Accident Boards and Commissions, 142 DEP'T LABOR BULL. 1 (1950). 
local legislation into accord with a provision the merit of which many of them doubt, and in the planning of which they were not consulted." 81

Such unfavorable response, lumping the efforts of the ILO and the State Department into a single nefarious plan for undermining state power, and coming from a body whose views the Department had carefully solicited, must have confirmed the treaty-makers in their growing desire to avoid trouble with the states-rightists on the workmen's compensation problem. ${ }^{82}$

The new policy found its touchstone in the deceptively simple concept of "national treatment." The standard itself was old, ${ }^{83}$ but beginning with the Uruguayan treaty it was given a predominant role. National treatment was made the governing principle of the treaty as a whole ${ }^{84}$ and the controlling standard of the workmen's compensation clause, ${ }^{85}$ and was defined within the text of the treaty as "treatment accorded within the territories of a Party upon terms no less favorable than the treatment accorded therein in like situations, to nationals, companies, products, vessels, or other objects, as the case may be, of such Party." 88

The general purport of this language is to ensure that aliens should get no benefits not accorded American citizens. ${ }^{87}$ Since all the discriminatory statutes bar nonresident alien dependents of citizen work-

81. Id. at 184-86.

82. One additional revealing sign of the State Department's wary approach to the federal-state issue is the consular treaty with Ireland signed in 1950. A consul is empowered to collect money to which a national may be entitled, but that power is heavily qualified by any local law that might forbid such action. Earlier treaties with the same empowering clause did not have the limitations. Convention and Supplementary Protocol With Ireland, May 1, 1950, art. XIX [1954] 1 U.S.T. \& O.I.A. 949, 988-89, T.I.A.S. No. 2984.

83. See Wilson, Access-to-Courts Provisions in United States Commercial Treaties, 47 AM. J. INT'L L. 19, 39 (1953) and BAyITCH, Conflict LAW IN UNITED States TREATIES 15 (1955).

84. Treaty With Uruguay on Friendship, Commerce, and Navigation, Nov. 23, 1949 (reprinted in 23 Dep'T State BuLc. 502 (1950)).

85. The workmen's compensation provision reads exactly the same as the comparable provision in the 1954 German treaty. See text accompanying note 2 supra.

86. Treaty With Uruguay on Friendship, Commerce, and Navigation, Nov. 23, 1949, art. XIX (reprinted in 23 DEP'T STATE BULL. 502 (1950)).

87. The themes of equality for American citizens and states rights are inextricably related. The Bricker element in the Senate Foreign Relations Committee has continually sought assurance from the State Department that aliens will get no better benefits than American citizens. Hearings Before the Subcommittee on Commercial Treaties of the Senate Committee on Foreign Relations, 80th Cong., 2d Sess. 13 (1948); Hearings Before the Subcommittee on Commercial Treaties of the Senate Comnittee on Foreign Relations, 82d Cong., 2d Sess. 15 (1952). The president of the state workmen's compensation commissioners feared that under provisions such as those in the Italian treaty or under convention 19 of the ILO an alien workman or dependent would get "what to him is a fortune." 142 DEP'T LABOR BUL.L. 185 (1950). 
men, as well as nonresident alien dependents of alien workmen, ${ }^{88}$ they do provide for equality of treatment cognizable by the "national treatment" clause. At least one case ${ }^{89}$ has in fact denied recovery to the nonresident alien dependent of a citizen workman; others have rejected the nonresident on the ground that he was receiving national treatment and could not therefore complain. ${ }^{90}$

Subsequent commercial agreements with Ireland, ${ }^{91}$ Greece, ${ }^{92}$ Israel, ${ }^{93}$ and Japan ${ }^{94}$ have restated the language of the Uruguayan treaty. In so firmly embracing the national treatment criterion, the federal government, at least in the workmen's compensation area, has thus made its peace with those forces seeking to limit the effects of the exercise of the treaty power upon the residual powers of the states. The national treatment standard, in short, reassures those states with discriminatory laws that they have met the test of recent treaties when their laws discriminate against nonresident alien dependents of American citizens as well as those of aliens.

The 1954 German treaty fits neatly into the pattern set by the Uruguayan agreement. The latter's preamble, ${ }^{95}$ compensation provision and definition of national treatment are repeated word-for-word. ${ }^{96}$

88. Digest of Workaien's CoMpensation Laws of the United States and TERRITORIES passim (16th ed. 1957).

89. Micasz v. Compensation Comm'r, 123 W. Va. 14, 13 S.E.2d 161 (1941).

90. See, e.g., Frasca v. City Coal Co., 97 Conn. 212, 116 Atl. 189 (1922), and Maryland Cas. Co. v. Chamos, $203 \mathrm{Ky} .820,263$ S.W. 370 (1924). The argument was raised in Iannone, 285 App. Div. at 754, 141 N.Y.S.2d at 314, and apparently denied largely because of the explicit wording of the 1948 Italian provision that severely qualifies the national treatment standard to the advantage of the nonresident alien dependent. But faced with the 1954 German treaty provision based, unlike the 1948 Italian, entirely on national treatment, even the court that decided the Iannome case would be susceptible to the argument denying nonresident alien recovery on this issue.

91. Treaty With Ireland on Friendship, Commerce, and Navigation, Jan. 21, 1950 [1950] U.S.T. \& O.I.A. 785, T.I.A.S. No. 2155.

92. Treaty With Greece on Friendship, Commerce, and Navigation, Aug. 3, 1951 [1954] 2 U.S.T. \& O.I.A. 1829, T.I.A.S. No. 3057.

93. Treaty With Israel on Friendship, Commerce, and Navigation, Aug. 23, 1951 [1954] 1 U.S.T. \& O.I.A. 550, T.I.A.S. No. 2984.

94. Treaty With Japan on Friendship, Commerce, and Navigation, April 2, 1953 [1953] 2 U.S.T. \& O.I.A. 2063, T.I.A.S. No. 2863.

95. See notes $84-86$ supra.

96. Except, of course, for the substitution of party names. And there is further evidence that the German treaty was not intended by the American negotiators to conflict with state law. A State Department official referring specifically to the 1954 German treaty told the Senate Foreign Relations Committee that "in its negotiation, the Department was guided by approved precedents and by the known views of the Senate concerning the proper scope and content of such an instrument. This treaty consequently contains no innovations raising new problems of reconciliation with domestic law." S. Ex. REP. No. 10, 84th Cong., 1st Sess. 8 (1955). The report of that committee emphasizes in turn that the treaty "does not impair the constitutional rights of American citizens, nor does it alter established Federal-State relations or enlarge Federal powers at the expense of the States." Id. at 3 . In addition, paragraph 4 of the protocol of the German treaty states that paragraph two of article IV (dealing with social insurance) does not apply to state law. This indicates the desire of the 
Whereas the 1923 German and the 1948 Italian provisions are framed in terms of specific application to the interests of nonresident alien dependents, ${ }^{97}$ article IV of the 1954 German treaty speaks simply of "Nationals of either Party . . . within the territories of the other Party." ${ }^{88}$ No reasonable reading of the earlier treaties could have made them consistent with the proposition that discrimination against nonresident alien dependents, if even-handed in the national treatment sense, was lawful. Yet the imprecision of the 1954 clause readily lends itself to such a construction. Since the courts have demonstrated a reluctance to read a treaty as conflicting with state law in the absence of an explicit command, the resort to broad language might operate practically as a mandate to the courts to permit discrimination.

Apart from the ambiguous, if not clearly exclusive, words of the provision, the dependent cannot easily say that the contracting parties intended to protect his rights. First, and this theory is related to the wording issue, had the parties wanted to include nonresident alien dependents they would have expressly done so. Furthermore, the argument would run, prior treaties did expressly include nonresident alien dependents, and the abrupt change in language since 1949 shows an intent not to include them now. Finally, the opponent could summon the extrinsic evidence such as that related above ${ }^{99}$ to show that the American negotiators did not intend to frame a provision that would clash with any state law.

\section{The Alien's Case Under Article IV: A Suggested Approach}

The German nonresident dependent can, nevertheless, effectively argue his case in American courts. And he can argue on the same issues of wording, intent, and national treatment discussed above.

While article IV does not actually mention nonresident alien dependents, one might say that it does include them by all reasonable implication. "Nationals of either party" 100 would seem to cover nonresident alien dependents. Although the phrase "within the territories

American negotiators to avoid conflict. It would, naturally, have been impossible to limit article IV, paragraph one, so openly since the great bulk of workmen's compensation is on a state level. Treaty of Friendship, Commerce, and Navigation With Germany, Oct. 29, 1954 [1956] 2 U.S.T. \& O.I.A. 1839, T.I.A.S. No. 3593.

97. Dependents are defined as "relatives and heirs or dependents of an injured party, . . . regardless of their alienage or residence outside of the territory where the injury occurred . ..." in the 1923 German treaty, and the language of the 1948 Italian treaty is still more specific. See text beginning at note 57 supra; see note 25 sitpra.

98. For complete wording, see note 2 supra.

99. See text beginning at note 71 supra.

100. See full text at note 2 supra. 
of the other" is ambiguous, ${ }^{101}$ it must be read as modifying the preceding words, "in the application of laws and regulations" ${ }^{102}$ rather than limiting "nationals" to mean nationals residing in the other's territory. Paragraph two of the same article relating to social insurance would corroborate this interpretation. ${ }^{103}$

Proceeding to the intent of the parties, the dependent could contend that neither the American nor German negotiators wanted to change the broad protection spelled out in the 1923 German model and in the recent Italian treaty. They merely wished to make the provision more concise. A State Department official has testified before the Senate Foreign Relations Committee that the treaty program has been undergoing a "modernization and streamlining." 104 Another officer stated before the same body that the new, post-1948 agreements were still part of the "modern phase" dating from 1923 and the German treaty of that year. ${ }^{105} \mathrm{He}$ likened the Uruguayan-type treaty to the 1948 Italian, saying that the former was only a restated form of the latter with "no real change . . . the general objectives remain the same . . . all the [new] treaties go about realizing these objectives in essentially the same way [as the old]." 106 The German treaty itself was referred to by the State Department as bearing a "common thread of similarity in . . . basic purpose, and underlying principle" ${ }^{107}$ to all the other post-World War II agreements.

Again, one might argue that, since the whole basis of the treaty is reciprocal in nature, the negotiators could not have intended to deny German nonresident alien dependents substantial rights that Americans in the same position are not denied in Germany. The preamble ${ }^{108}$ of the German treaty and many of the reports associated with it emphasize

101. See discussion in text regarding wording of the provision at note 98 supra.

102. See full text at note 2 supra.

103. "Nationals of either Party shall furthermore be accorded national treatment with regard to the application of social security laws and regulations within the territories of the Party under which benefits are provided. . . "Treaty of Friendship, Commerce, and Navigation With Germany, Oct. 29, 1954, art. IV [1956] 2 U.S.T. \& O.I.A. 1839, T.I.A.S. No. 3593.

104. Hearings Before the Subcommittee on Commercial Treaties of the Senate Committee on Foreign Relations, 84th Cong., 2d Sess. 10 (1956). In fact, some Senators expressed fear that the provisions might be getting too simple. Id. at 19.

105. Hearings Before the Subcommittee on Commercial Treaties of the Senate Committee on Foreign Relations, 82d Cong., 2d Sess. 16 (1952).

106. Ibid. In his report to the President on the German Treaty, Secretary of State Dulles also remarked, "[T] he present treaty follows the general pattern established by the 10 treaties of this type previously negotiated between the United States and other countries since World War II. . . " S. Ex. Doc. E., 84th Cong., 1st Sess. 3 (1955).

107. S. Ex. Rep. No. 10, 84th Cong., 1st Sess. 8 (1955).

108. "[B]ased in general upon the principles of national . . treatment reciprocally accorded." Treaty of Friendship, Commerce, and Navigation With Germany, Oct. 29, 1954 [1956] 2 U.S.T. \& O.I.A. 1839, T.I.A.S. No. 3593. 
its reciprocal nature. ${ }^{109}$ And the Assistant Secretary for Economic Affairs told the Senate Foreign Relations Committee that under treaties of the German type, "rights assured to Americans in foreign countries are assured in equal measure to foreigners in this country." 110 An interpretation of article IV excluding nonresident alien dependents could hardly fulfill this announced intention of reciprocity.

Furthermore, could the parties have intended to create a situation where an alien workman who is slightly injured can obtain compensation within a state with discriminatory laws while his nonresident alien dependents cannot obtain full compensation from his death? Yet this is the result if the treaty provision is not construed to cover his dependents. ${ }^{111}$

As a final strong argument on intent, the dependent could point to the fact that the 1923 German treaty provisions regarding the rights of consuls ${ }^{112}$ were expressly continued in force by an agreement made in 1953. ${ }^{113}$ The parties writing the 1954 treaty could not have meant to exclude nonresident alien dependents from workmen's compensation when article XXV of the reaffirmed consular treaty specifically empowers a consular officer to collect that compensation when awarded.

The greatest obstacle to recovery would in all likelihood be the national treatment argument outlined earlier. ${ }^{114}$ But there are rallying points even on this ground. While it is possible to interpret national treatment as allowing for discrimination against nonresident alien dependents, provided that the dependents of citizen and alien workmen are treated alike, such a reading would render the provision in large measure meaningless. Obviously not intended to alter the effects of state laws which do not discriminate, paragraph one of article IV is directed at legislation which does discriminate. If national treatment means that states which discriminate can continue to do so, as suggested, then the treaty provision has no effect at all and is nullified. When a given construction would render a provision meaningless, there is good precedent for rejecting that construction. ${ }^{115}$

109. S. Ex. REP. No. 10, 84th Cong., 1st Sess. 1 (1955) : "[T]he pending treaty will assure, on a reciprocal basis..."; see also the State Department report. Id. at 8.

110. Hearings, supra note 105 , at 16.

111. See Andrews, Discrimination Against Non-Resident Dependents, 13 AMr. LAB. LEG. Rev. 232, 233-34 (1923).

112. Treaty With Germany on Consular Rights, June 3, 1953 [1954] 2 U.S.T. \& O.I.A. 1939, T.I.A.S. No. 3062.

113. For the wording of the now-revived consular provision, see text accompanying note 58 stipra.

114. See discussion in text beginning at note 87 supra.

115. See, e.g., Hauenstein v. Lynham, 100 U.S. 483 (1879). One could argue, furthermore, that the new German article is broader in scope than the old. In not 
If the dependent cannot establish the above approach to national treatment, the court's interpretation of national treatment in the Iannone case can be quoted as valuable precedent for an alternative argument: national treatment does not mean the weighing of the treatment of citizen workmen with nonresident alien dependents and of alien workmen with similar dependents, but the matching of the nonresident widow abroad with the citizen widow in the United States:

"The respondents argue that section 17 is not discriminatory because it applies not only to non-resident alien dependents of a deceased alien-employee but also to non-resident alien dependents of a deceased citizen-employee. However, the rights of dependents to death benefits are created by law and not derived from any right conferred upon a deceased employee. . . . The benefits accrue not to the deceased employee or his estate but directly to his dependents. The comparison to be made should be as to the treatment of non-resident Italian dependents and dependents who are United States nationals. When that is done, we find the treatment of non-resident Italian dependents less favorable and, therefore, in violation of the Treaty." 116

Finally, the definition of national treatment in article XXV of the 1954 German treaty can be construed to further this alternative view of the standard. If' national treatment means "treatment . . . no less favorable than the treatment accorded therein in like situations, to nationals . . . of such Party," 117 it can hardly be said reasonable, in reference to nonresident alien dependents, that "like situations" refers to the situation of that handful of citizen workmen in the United States who have nonresident alien dependents. It must be directed to American national dependents obtaining full benefits in the event of the laborer's death. In this sense, a German widow of a worker killed on the job in the United States is entitled to the same treatment as an

singling out dependents for equal treatment, it embodies at last the theory broached in McGovern v. Philadelphia \& Reading R.R., 235 U.S. 389 (1914), and Madera Sugar Pine Co. v. Industrial Acc. Comm'n, 262 U.S. 499 (1923), but stifled in Maiorano and Liberato, that national treatment is not given only to the dependents in an industrial context but to the workman and his family in their whole relation to the industrial economy: "Likewise the treaty has underlying it a sound public policy. At times, when labor is abundant, American employers might be prevented from employing American workmen in dangerous occupations, if, by employing aliens having non-resident alien beneficiaries, they are safeguarded against the payment of benefits to non-resident widows and dependents of such aliens, in case of death or injury . . . and thus in such times of abundant labor there would be discrimination against American labor." Antosz v. State Compensation Comm'r, 130 W. Va. 260, 267-68, 43 S.E.2d 397, 401 (1947).

116. 285 App. Div. at 754-55, 141 N.Y.S.2d at 314. The strong effect of this argument, at least in New York, is shown in Viselli v. Martino, 285 App. Div. 1195, 140 N.Y.S.2d 643 (1955).

117. Treaty With Uruguay on Friendship, Commerce, and Navigation, Nov. 23, 1949, art. XIX (reprinted in 23 DEP'T STATE Bull. 502 (1950)). (Emphasis added.) 
American widow of an American worker killed on the job. The American and German widow are in "like situations."

Whatever the force of the above arguments, article IV will ultimately be tested in American courts. At that time it may be hoped that under the treaty power it will be enforced against discriminatory state law. For through its recent treaty with Germany, the United States has undertaken deep obligations of social welfare toward the people of that nation. In referring to treaties of the German type, the State Department itself has said that "domestically these treaties reinforce in terms of international obligation the position of the Federal Government as guardian of the rights of foreigners." 118 It would be unfortunate if the United States neglected that guardian's role by failing to protect the rights of nonresident German dependents seeking compensation for industrial death.

118. 24 Dep't State Bull. 746 (1951). 